\title{
Effect of pulse high-volume hemofiltration on Toll-like receptor in patients with severe sepsis
}

\author{
NING ZHANG $^{1 *}$, JIAN ZHANG ${ }^{1 *}$, ZHUO CAO $^{2}$, \\ LIANCHENG DENG ${ }^{1}$, YIFEN WU ${ }^{1}$, HONG LIU ${ }^{1}$ and ZELIANG QIU ${ }^{3}$
}

Departments of ${ }^{1}$ Critical Care Medicine and ${ }^{2}$ Respiratory Medicine, Lishui People's Hospital, Lishui, Zhejiang 323000; ${ }^{3}$ Department of Critical Care Medicine, The Affiliated Zhoupu Hospital of Shanghai University of Medicine \& Health Sciences, Shanghai 201318, P.R. China

Received November 2, 2015; Accepted June 23, 2016

DOI: $10.3892 / e t m .2016 .3473$

\begin{abstract}
The expression level and prognosis of Toll-like receptor 2 (TLR2) mRNA in peripheral blood mononuclear cells of patients with severe sepsis after applying pulse high-volume hemofiltration (PHVHF) were investigated. Sustained PHVHF treatment was carried out on 40 patients on the basis of conventional treatment for up to $72 \mathrm{~h}$. Acute physiology and chronic health evaluation (APACHE) II scores of patients were compared before and after the treatment. $\mathrm{CD} 4^{+}, \mathrm{CD} 8^{+}$lymphocyte counts and ratios in the peripheral blood were detected using FASort before and 24 and $48 \mathrm{~h}$ of PHVHF treatment. Enzyme-linked immunosorbent assay was adopted to detect tumor necrosis factor- $\alpha$ (TNF- $\alpha$ ) and interleukin-10 (IL-10) concentrations in plasma at different time points before and after 24,48 and $72 \mathrm{~h}$ of treatment, while semi-quantitative reverse transcription-polymerase chain reaction technology was used to test TLR2 mRNA expression. After PHVHF treatment, APACHE II, Sequential Organ Failure Assessment scores were decreased $(\mathrm{P}<0.05)$. After $72 \mathrm{~h}$ of PHVHF treat-ment, TNF- $\alpha$, IL-10, TLR2 mRNA expression levels in the plasma of patients were significantly decreased compared to before treatment $(\mathrm{P}<0.05)$, and the IL-10 / TNF- $\alpha$ ratio was much higher than before treatment $(\mathrm{p}<0.05)$. In conclusion, PHVHF can restore the pro-inflammatory/anti-inflammatory balance of the body, thereby improving the overall condition of the patients by removing inflammatory mediators and lowering TLR2 expression of mononuclear cell surface in peripheral blood.
\end{abstract}

Correspondence to: Dr Zeliang Qiu, Department of Critical Care Medicine, The Affiliated Zhoupu Hospital of Shanghai University of Medicine \& Health Sciences, 1500 Zhouyuan Road, Shanghai 201318, P.R. China

E-mail: qiuzeliang201506@163.com

*Contributed equally

Key words: hemofiltration, sepsis, Toll-like receptor 2

\section{Introduction}

Sepsis is an uncontrolled systemic inflammatory reaction caused by the excessive release of pro-inflammatory mediators in the body, which in turn causes tissue damage, shock and multi-organ failure. Continuous high-volume hemofiltration (HVHF) has been used for the treatment of severe sepsis, which could non-selectively remove inflammatory mediators and has a preferred impact on physiological index and survival time (1-4). However, HVHF has a high cost and is technically complicated. However, although the pulse HVHF (PHVHF) has overcome these shortcomings, the mechanism of PHVHF treatment of sepsis is not yet clear.

$\mathrm{T}$ lymphocytes are important inflammatory cells involved in sepsis. T cells are a population of cells with a variety of functions, and play an important role in the regulation of immune reactions. The number and proportion of $\mathrm{T}$ lymphocytes is an important indicator of the level of immunity of the body (5). The CD molecule on the T-cell surface is not only a product of T-cell differentiation, but also the molecular basis whereby $\mathrm{T}$ cells can play their biological function. Depending on the type of cytokine secretion, $\mathrm{CD} 4^{+} \mathrm{T}$ lymphocytes are divided into the Th1 and Th2 subtypes. The two subtypes respectively promote the immune responses of cell meditation and enhance immune response of antibody meditation $(6,7)$. The main function of $\mathrm{CD}^{+} \mathrm{T}$ lymphocytes is that these can specifically kill target cells and play an important role in the immune response of $\mathrm{T}$ cells $(8,9)$. The number and ratio of CD8 and T lymphocytes is required to determine the status of the immune system of patients prior to and after the treatment.

Toll-like receptors (TLRs) are important pattern recognition receptors that can mediate a wide variety of pathogenic microorganisms and their products to cause cell signal transduction activity of similar properties and production of cytokines (10). Activation of nuclear factor- $\mathrm{KB}(\mathrm{NF}-\kappa \mathrm{B})$ and other nuclear transcription factors promote the transcription and synthesis of tumor necrosis factor- $\alpha$ (TNF- $\alpha$ ), interleukin-6 (IL-6) and other inflammatory mediators, thereby stimulating the body's inflammatory response (11). Thus, TLRs play a vital role in the mechanism of development of sepsis. In the present study, we examined the expression levels of TLR2 mRNA in order to understand the mechanism of PHVHF treatment in sepsis. 
TNF- $\alpha$ is a central part of the complex network of the inflammatory mediators of sepsis, as well as key pro-inflammatory cytokines leading to the uncontrolled release of inflammatory mediators (12). IL-10 is an essential negative regulator and anti-inflammatory neurotransmitter. It was previously shown that in severe sepsis, the balance between inflammatory factors and anti-inflammatory factors exerts an important influence on the state and survival rate of patients (13). IL-10/TNF- $\alpha$ to some extent, is the contrast of anti-inflammatory and pro-inflammatory forces in the body.

The present study aimed to obtain preliminary results of a possible PHVHF therapeutic mechanism for patients with severe sepsis by testing the number and ratio of $\mathrm{CD}^{+}$and $\mathrm{CD} 8^{+} \mathrm{T}$ lymphocytes in the peripheral blood of patients and the expression level of TLR2 mRNA and the ratio of IL-10/ TNF- $\alpha$ in the blood prior to and after PHVHF treatment.

\section{Materials and methods}

General data. Forty patients with severe sepsis who were hospitalized at the Lishui City People's Hospital from March, 2009 to March, 2011 were included. Inclusion criteria were: i) Age, $\geq 18$ years; ii) meet the diagnostic criteria of severe sepsis according to the International Conference in 2001 as participated by the Critical Care Medicine/European Society of Intensive Care Medicine/American College of Chest Physicians/American Thoracic Society/Surgical Infection Society (14).

The exclusion criteria for the study were: i) Patients who had received immunomodulatory treatment within a month; and ii) patients who had been given continued venous hemofiltration $(\mathrm{CVVH})$ treatment prior to hospitalization.

Treatments. Patients received conventional treatment according to recently developed management guidelines for severe sepsis (15), including active treatment of the primary disease, fluid resuscitation, appropriate administration of antimicrobial agents, analgesic and sedation, blood glucose control, nutritional support and support therapy of major organ function. The PHVHF treatment was conducted on the basis of conventional therapy $2 \mathrm{~h}$ after the selection of patients. A $14 \mathrm{~F}$ double lumen catheter (Arrow, Asheboro, NC, USA) was selected and catheterized in the jugular or subclavian vein to establish vascular access blood flow to meet the capacity of $250-300 \mathrm{ml} / \mathrm{min}$. Using Prismaflex bedside blood filter produced by Gambro AB (Lakewood, CO, USA) an M100 set (acrylonitrile and sodium methylsulfonate copolymer hydrogel film) was selected and replaced every24 h. Bicarbonate-buffered hemofiltration fluid (BloodPurification Center of Lishui People's Hospital) was administered as predilution (50\%) and postdilution (50\%). PHVHF was performed using an ultrafiltration (UF) rate of $85 \mathrm{ml} / \mathrm{kg} / \mathrm{h}$ for $6 \mathrm{~h} /$ day followed by standard CVVH (UF rate $35 \mathrm{ml} / \mathrm{kg} / \mathrm{h}$ ) for $18 \mathrm{~h}$, resulting in a cumulative dose of $\sim 48 \mathrm{ml} / \mathrm{kg} / \mathrm{h}$. Treatment lasted $\geq 72 \mathrm{~h}$. Net ultrafiltration was determined by the specific condition of patients and clinical need. As for anticoagulation, the first loading dose of unfractionated heparin was 25-30 IU/kg intravenously, followed by continuous intravenous pump infusion at the speed of $5-10 \mathrm{IU} / \mathrm{kg} / \mathrm{h}$. Activated partial thromboplastin time was monitored every 4-6 h, maintaining 1- to 1.5 -fold of its normal value.
Clinical observations. Appropriate laboratory and physiological indicators of the patients prior to and after $72 \mathrm{~h}$ of treatment for acute physiology and chronic health evaluation (APACHE) II were recorded. A routine blood chemistry test, arterial blood gas analysis and lactate values were recorded and arterial oxygenation index $\left(\mathrm{PaO}_{2} / \mathrm{FiO}_{2}\right)$ was calculated.

Test of T-lymphocyte subsets in the peripheral blood. Heparin, an anticoagulant was assessed by inspection within $6 \mathrm{~h}$ at the beginning of treatment, then 24 and $48 \mathrm{~h}$ after treatment. FACSort (Becton Dickinson, San José, CA, USA) was used to test $\mathrm{CD}^{+}, \mathrm{CD}^{+}$lymphocyte count, and $\mathrm{CD} 4^{+} / \mathrm{CD}^{+}$ ratio in the peripheral blood using a kit purchased from $\mathrm{BD}$ Biosciences (Franklin Lakes, NJ, USA).

Enzyme-linked immunosorbent assay (ELISA). Venous blood $(5.0 \mathrm{ml})$ was drawn from the patients prior to and after 24 , 48 and $72 \mathrm{~h}$ of treatment, and $1.091 \mathrm{~mol} /$ citrate at 9:1 was used for anticoagulation. Blood was centrifuged at $700 \mathrm{x} \mathrm{g}$ for $10 \mathrm{~min}$, and the serum was stored at $-40^{\circ} \mathrm{C}$. ELISA was used to test the concentration of TNF- $\alpha$ and IL-10 in the plasma. The ELISA kit was obtained from Shenzhen Jingmei Biotech Co., Ltd. (Shenzhen, China). Each sample was measured twice and the average was taken.

Reverse transcription $(R T)$-polymerase chain reaction detection of TLR2 $m R N A$. Peripheral blood $(5 \mathrm{ml})$ was extracted after 24, 48 and $72 \mathrm{~h}$ of treatment, and heparin was used for anticoagulation. Ficoll density gradient centrifugation was employed to separate peripheral blood mononuclear cells (PBMC) and the one-step TRIzol reagent extraction method was used to extract total RNA. RT-PCR was performed in $2 \mu \mathrm{l}$ of RNA samples. Primers were designed according to the target gene mRNA sequence in the Genbank sequence databases: upstream, 5'-CAGGAGCTCTTAGTGACCAAGT GAA-3'; downstream, 5'-CACAAAGTATGTGGCATTGTC CAG-3'. After the gel electrophoresis of the amplicon with agarose of mass fraction of $1.5 \%$, the electrophoresis results were viewed with a gel imaging system produced by Amersham Pharmacia (Piscataway, NJ, USA), and analyzed by gel imaging system with Quantity One software (Bio-Rad, Hercules, CA, USA). The relative expression level of mRNA was shown by means of the ratio between target gene and $\beta$-actin.

Determination of inflammatory markers. Venous blood $(5.0 \mathrm{ml})$ was extracted before and after 24,48 and $72 \mathrm{~h}$ of treatment, and $1.091 \mathrm{~mol} / \mathrm{citrate}$ at 9:1 was used for anticoagulation.

Blood was centrifuged at $700 \mathrm{xg}$ for $10 \mathrm{~min}$, and the serum was stored at $-40^{\circ} \mathrm{C}$. C-reactive protein (CRP) was tested with rate transmission turbidimetry purchased from Randox Laboratories-US, Ltd. (Kearneysville, WV, USA) and supporting reagents. A number of peripheral blood white blood cells was detected with blood routine examination.

Statistical analysis. SPSS 20.0 statistical software (IBM SPSS, Armonk, NY, USA) was used to carry out data analysis. Data analysis was presented as mean \pm standard deviation. A comparison between the groups was carried out using the 
Table I. Comparison of oxygen metabolism and APACHE II scores at each time point before and after treatment.

\begin{tabular}{lccccc}
\hline Time points & $\mathrm{pH}$ & $\mathrm{PaO}_{2} / \mathrm{mmHg}$ & $\mathrm{PaO}_{2} / \mathrm{FiO}_{2}$ & $\mathrm{LA}(\mathrm{mmol} / \mathrm{l})$ & APACHE II \\
\hline Before treatment & $7.22 \pm 0.13$ & $78 \pm 13$ & $165 \pm 48$ & $7.8 \pm 4.2$ & $29.3 \pm 4.4$ \\
After 24 h & $7.34 \pm 0.08$ & $89 \pm 12^{\mathrm{a}}$ & $206 \pm 42^{\mathrm{a}}$ & $4.8 \pm 1.2^{\mathrm{a}}$ & $26.4 \pm 5.1$ \\
After 48 h & $7.45 \pm 0.10$ & $90 \pm 19^{\mathrm{a}}$ & $225 \pm 80^{\mathrm{a}}$ & $3.8 \pm 1.0^{\mathrm{a}}$ & $20.5 \pm 4.1^{\mathrm{a}}$ \\
After 72 h & $7.42 \pm 0.12$ & $98 \pm 16^{\mathrm{a}}$ & $228 \pm 76^{\mathrm{a}}$ & $2.0 \pm 0.8^{\mathrm{a}}$ & $15.3 \pm 3.1^{\mathrm{a}}$ \\
\hline
\end{tabular}

Compared to before treatment ${ }^{\mathrm{a}} \mathrm{P}<0.05$. LA, lactate values; APACHE, acute physiology and chronic health evaluation.

bunching t-test, while the paired t-test was used to make comparisons between groups. Analysis of variance was applied to make pairwise comparisons among various samples. Count data were determined using the $\chi^{2}$ test. $\mathrm{P}<0.05$ was considered to indicate a statistically significant difference.

\section{Results}

General. Eligible patients were 18-72 years of age. Among them, there were 9 cases of severe acute pancreatitis, 16 cases of pulmonary infection, 5 cases of acute suppurative cholangitis peritonitis, 7 cases of intestinal rupture complicated by intra-abdominal infections, 2 cases of cholecystitis, and 1 case of severe burns. Most of the patients had more than two types of complications and all the patients received PHVHF treatment.

APECHE II score and oxygen metabolism improves following treatment. Compared to before treatment, oxygen metabolism after 24, 48 and $72 \mathrm{~h}$ of treatment, showed $\mathrm{PaO}_{2}$, the $\mathrm{PaO}_{2} / \mathrm{FO}_{2}$ ratio was significantly improved, and blood lactate levels were considerably decreased. The $\mathrm{pH}$ of the blood showed no significant change prior to and following treatment. APACHE II scores showed significant improvement after $48 \mathrm{~h}$ of treatment. After $72 \mathrm{~h}$ treatment, the APACHE II score decreased further (Table I).

Results of peripheral blood T lymphocyte subsets following treatment. After 24 and $48 \mathrm{~h}$ treatment, the peripheral blood CD4 ${ }^{+}$T-cell counts of patients with sepsis increased significantly compared to before treatment $(\mathrm{p}<0.05)$, but the $\mathrm{CD} 8^{+}$ $\mathrm{T}$ cells showed no obvious increase. The resulting $\mathrm{CD}^{+} / \mathrm{CD}^{+}$ ratio markedly increased following treatment $(\mathrm{p}<0.05)$, and as therapy continued, the $\mathrm{CD} 4^{+} / \mathrm{CD}^{+}$ratio increased more significantly after $48 \mathrm{~h}$ treatment $(\mathrm{p}<0.01)$ (Table II).

Change in blood cytokine concentrations at different time points prior to and following treatment. After $48 \mathrm{~h}$ treatment, the concentration of TNF- $\alpha$ and IL-10 in the serum was significantly decreased $(\mathrm{p}<0.05)$ compared to before treatment, although the ratio between the two did not change. After $72 \mathrm{~h}$ treatment, TNF- $\alpha$ and IL-10 concentrations in the blood were significantly decreased compared to before treatment $(\mathrm{p}<0.05)$. Additionally, the IL-10/TNF- $\alpha$ ratio was much higher than before treatment $(\mathrm{p}<0.05)$. Similarly, after $72 \mathrm{~h}$ treatment, TLR2 mRNA was evidently decreased than before treatment $(\mathrm{p}<0.05)$ (Table III).
Table II. Peripheral blood T lymphocyte subsets at different time points.

\begin{tabular}{llll}
\hline Observation time & $\mathrm{CD}^{+}(\%)$ & $\mathrm{CD}^{+}(\%)$ & $\mathrm{CD}^{+} / \mathrm{CD}^{+}$ \\
\hline Start of treatment & $23.20 \pm 8.6$ & $21.90 \pm 9.5$ & $1.26 \pm 0.7$ \\
$24 \mathrm{~h}$ & $28.30 \pm 9.0^{\mathrm{a}}$ & $20.70 \pm 7.6$ & $1.56 \pm 0.7^{\mathrm{a}}$ \\
$48 \mathrm{~h}$ & $30.90 \pm 8.9^{\mathrm{a}}$ & $20.30 \pm 8.1$ & $1.73 \pm 0.8^{\mathrm{b}}$ \\
\hline
\end{tabular}

Compared to before treatment ${ }^{\mathrm{a}} \mathrm{P}<0.05,{ }^{\mathrm{b}} \mathrm{P}<0.01$.

Changes in inflammatory markers following treatment. After $48 \mathrm{~h}$ treatment, inflammatory markers, peripheral blood leukocyte count [white blood cell (WBC)] and CRP showed a significant decrease $(\mathrm{p}<0.05)$ (Table IV).

\section{Discussion}

Sepsis and related septic shock with multiple organ dysfunction syndrome is the leading cause of death in the intensive care unit at present (16), as well as the main focus and difficulties facing contemporary critical care medicine. A series of changes in hemodynamics and metabolic processes occurring in sepsis is caused by the production and excessive release of inflammatory mediators; thus, early control and removal of inflammatory factors is the key to treatment. In recent years, HVHF has been used for the treatment of severe sepsis, which can non-selectively remove inflammatory mediators, improve symptoms, stabilize hemodynamics and reverse organ damage, and reduce mortality $(2,17,18)$. However, HVHF requires high blood flow, stringent ultrafiltration control and a large amount of high-priced sterile replacement fluid, which makes HVHF expensive and together with its complex technology, its clinical application is limited. In 2004, PHVHF technology was suggested by Brendolan to solve the issue (19). Previous findings showed that for treatment of severe sepsis, PHVHF can improve hemodynamics, decrease inflammatory mediator response, and restore the immune balance (20-23). Our results showed that, PHVHF can improve clinical symptoms of patients with severe sepsis, and reduce the APACHE II score.

$\mathrm{T}$ cells are a population of cells with a range of functions and are crucial in the regulation of various immune reactions. Hotchkiss et al (24) found that, $\mathrm{CD}^{+}$and $\mathrm{CD}^{+} \mathrm{T}$-lymphocyte apoptosis is increased in patients with sepsis relative to non-sepsis patients. Therefore, the increase of $\mathrm{CD}^{+}$and $\mathrm{CD}^{+} \mathrm{T}$ lymphocytes may be beneficial to patients with sepsis. 
Table III. Comparison of TLR2 mRNA and TNF- $\alpha$, IL-10, IL-10/TNF- $\alpha$ between the two groups of patients at different time points (mean \pm standard deviation).

\begin{tabular}{lcccc}
\hline Time points & TLR2 mRNA & TNF- $\alpha$, ng/l & IL-10, ng/l & IL-10/TNF- $\alpha$ \\
\hline Before treatment & $1.81 \pm 0.15$ & $492.20 \pm 100.80$ & $253.30 \pm 47.70$ & $0.51 \pm 0.18$ \\
$24 \mathrm{~h}$ & $1.90 \pm 0.96$ & $470.90 \pm 122.90$ & $245.20 \pm 44.90$ & $0.52 \pm 0.11$ \\
$48 \mathrm{~h}$ & $1.85 \pm 0.18$ & $431.90 \pm 53.00^{\mathrm{a}}$ & $179.50 \pm 28.80^{\mathrm{a}}$ & $0.48 \pm 0.31$ \\
$72 \mathrm{~h}$ & $1.47 \pm 0.15^{\mathrm{a}}$ & $303.60 \pm 49.20^{\mathrm{a}}$ & $184.20 \pm 18.80^{\mathrm{a}}$ & $0.63 \pm 0.25^{\mathrm{a}}$ \\
\hline
\end{tabular}

Compared to before treatment ${ }^{\mathrm{a}} \mathrm{p}<0.05$. TLR2, Toll-like receptor 2 ; IL-10, interleukin-10; TNF- $\alpha$, tumor necrosis factor- $\alpha$.

Table IV. Inflammatory markers before and after treatment.

\begin{tabular}{lccrr}
\hline Markers & $\begin{array}{c}\text { Before } \\
\text { treatment }\end{array}$ & $24 \mathrm{~h}$ & $48 \mathrm{~h}$ & $72 \mathrm{~h}$ \\
\hline CRP, mg/dl & $124 \pm 35$ & $122 \pm 19$ & $75 \pm 36^{\mathrm{a}}$ & $69 \pm 23^{\mathrm{a}}$ \\
WBC, $\mathrm{x} 10^{9} / 1$ & $21.3 \pm 4.4$ & $20.1 \pm 3.5$ & $15.0 \pm 4.1^{\mathrm{a}}$ & $10.3 \pm 2.9^{\mathrm{a}}$ \\
\hline
\end{tabular}

Compared to treatment ${ }^{\mathrm{a}} \mathrm{p}<0.05 . \mathrm{CRP}, \mathrm{C}$-reactive protein; $\mathrm{WBC}$, white blood cell.

Chen et al (25) identified that $\mathrm{CD} 4^{+} \mathrm{T}$ lymphocytes in survivors with sepsis outnumber those in the non-survivors. However, the number of $\mathrm{CD}^{+} \mathrm{T}$ lymphocytes between survivors and non-survivors demonstrated no significant differences, and the $\mathrm{CD} 4^{+} / \mathrm{CD}^{+}$ratio was also higher than that of non-survivors. The findings of that study are consistent with those of the present study, thus the increase in $\mathrm{CD} 4^{+} \mathrm{T}$ lymphocytes may increase the survival rate of patients with sepsis.

In 1996, Bone (13) suggested a new hypothesis on systemic inflammation and multiple organ dysfunction syndrome (MODS) etiology. This hypothesis holds that inflammation causes inflammatory mediators and induces anti-inflammatory mediators, and the inflammatory outcome depends on the balance of these substances, emphasizing the significance of maintaining a pro- and anti-inflammatory balance in the treatment of sepsis, which is more important than the simple level of pro-inflammatory cytokines. A study confirmed that the balance between inflammatory and anti-inflammatory cytokines is closely associated with severity and survival of sepsis in mice (26). Inflammatory mediator TNF- $\alpha$ is a central link of the complex network of inflammatory cytokines in sepsis. TNF- $\alpha$ is a leading pro-inflammatory cytokine that causes the uncontrolled release of inflammatory mediators (27). It is also the induction factor of many inflammatory cytokines, such as IL-1 $\beta$, IL-6 and IL-8. IL-10, which is an important immune-negative regulator, and immune and inflammatory neurotransmitter, can be detected in the blood in the different states of systemic diseases and inflammation (28). The ratio of IL-10/TNF- $\alpha$, in a way, represents the comparative strength of the pro- and anti-inflammatory response. The study identified that plasma TNF- $\alpha$ was markedly increased prior to treatment, and decreased after PHVHF treatment, suggesting that inflammatory response takes predominance during early severe sepsis, which is mainly dominated by pro-inflammatory cytokines. Following PHVHF treatment, the IL-10/TNF- $\alpha$ ratio apparently increased compared with the conventional treatment group, suggesting that the pro-inflammatory effect was markedly reduced, and that the imbalance between the pro-/anti-inflammatory response was partially corrected, leading to the uncontrolled inflammatory response in the body being alleviated.

The TLR family belongs to the IL-1R/TLR superfamily, which are important pattern recognition receptors that play an important role in the anti-microbial infection of the host $(24,25)$. These are mainly distributed on the surface of immune cells and epithelial cell cavities that connect to the outside world, with a richer expression on the surface of professional antigen-presenting cells, macrophages, and dendritic cells. Different TLR molecules recognize different pathogen-associated molecular patterns, and their identification/binding trigger a series of signal transductions, leading to the release of inflammatory mediators. These mediators play an important role in the innate immune response, and eventually activates the acquired immune system. In the TLR family, TLR2 has the broadest expression, and identifies most types of pathogenic microorganisms and their products. It can identify the cell wall component lipopolysaccharide of gram-negative bacteria, peptidoglycan cell wall component of gram-positive bacteria, lipoteichoic wall acid, and the full gram-positive bacteria. In addition, in mycobacterium spirochetes mycoplasma and yeast infections, TLR2 can activate intracellular signal transduction by identifying components of bacteria such as lipoarabinomannan, lipoproteins/lipopeptides and bacterial DNA (29). The interaction between the receptor structure of intracellular Toll/IL-1 of activated TLR2 and myeloid differentiation factor 88 carboxy activated the latter, which in turn stimulated the associated factor 6 of TNF- $\alpha$ receptor, and resulted in the degradation of NF- $\mathrm{\kappa B}$ by inhibiting protein phosphorylation, promoting the relocation of NF- $\mathrm{kB}$ to the nucleus to activate transcription of the corresponding gene, which advanced the synthesis of cytokines (TNF- $\alpha$, IL-1, IL-8, IL-10 and IL-12) to initiate inflammatory reactions $(30,31)$. Uncontrolled release of inflammatory mediators lead to the development of sepsis or even MODS. The present findings identified that after PHVHF treatment, TLR2 levels decreased significantly compared to the conventional treatment group, suggesting that PHVHF can lower the expression of TLR2 monocytes, thus weakening its role in the signal transduction pathways and keeping the excessive inflammation under control, thereby reducing the damage to the body's tissues and organs caused by the generation of 
large numbers of cytokines and inflammatory mediators, leading to the development of severe sepsis under control. Several studies have shown that pro-inflammatory mediators (IL-1, IL-6 and TNF- $\alpha$ ) can promote the upregulation of TLRs. Pro-inflammatory cytokines and TLRs form a positive feedback loop, but anti-inflammatory cytokines (IL-4 and IL-10) inhibit the upregulation of TLRs (32-34). In the early severe sepsis, the body continues to express high levels of TLR2 receptors, resulting in a large number of inflammatory cytokines with pro-inflammatory cytokines taking the dominant position, and it exerts a positive feedback regulation on TLR, leading to uncontrolled inflammation.

Our study showed that, as the PHVHF treatment continued, the number of $\mathrm{CD}^{+} \mathrm{T}$ lymphocytes increased and inflammatory cytokines were eliminated. The oxygenation ability was evidently improved, arterial blood lactate levels were gradually restored, and the APACHE II score was decreased significantly. This may be due to the effective removal of cytokine as hemofiltration restored the balance between pro- and anti-inflammatory factors, thereby interrupting the subsequent 'waterfall' effect of a series of inflammations, and avoiding oxygenation disorders of the body due to pulmonary edema and focal atelectasis, and ultimately achieving normal tissue perfusion.

In this study, the blood cytokines levels were decreased significantly after $48 \mathrm{~h}$ of PHVHF treatment, but the ratio of TLR2 mRNA and IL-10/TNF- $\alpha$ did not change. By contrast, after $72 \mathrm{~h}$ of treatment, content of TLR2 mRNA, IL-10, and TNF- $\alpha$ in the blood decreased significantly. The ratio of IL-10/TNF- $\alpha$ also showed significant upregulation, indicating that in early PHVHF treatment, improving symptoms is mainly achieved by the non-selective removal of inflammatory mediators. TLR2 mRNA was also eliminated with the ongoing treatment, which caused a significant reduction of inflammatory cytokines. TNF- $\alpha$ was mediated by TLR2, while the anti-inflammatory cytokine IL-10 did not have a greater change, thus increasing the IL-10/TNF- $\alpha$ ratio back to the normal anti-/pro-inflammatory balance, thus, the body inflammation was relieved. Obvious differences were evident by evaluating inflammatory markers CRP and WBC, indicating that the inflammatory response was reduced after the treatment.

In conclusion, by removing inflammatory mediators, PHVHF decreased the expression of its PBMC surface TLR2, and achieved the body's pro-/anti-inflammatory balance. Conducting specificity regulation on TLR2, an important part of the treatment, is a potential mechanism for treating sepsis.

\section{Acknowledgements}

The present study was supported by the Seed Foundation of the Shanghai University of Medicine \& Health Sciences (key project) (grant no.: HMSF-16-21-026) and the Medical Key Subject of Science and Technology Project in Lishui, no. 2010ZDXK13. The study was also supported by the cultivation of high level talents in Lishui, no. 2013RC05.

\section{References}

1. Li C, Zhang P, Cheng X and Chen J: High-volume hemofiltration reduces the expression of myocardial tumor necrosis factor-alpha in septic shock pigs. Artif Organs 37: 196-202, 2013.
2. Boussekey N, Chiche A, Faure K, Devos P, Guery B, D'Escrivan T, Georges $\mathrm{H}$ and Leroy $\mathrm{O}$ : A pilot randomized study comparing high and low volume hemofiltration on vasopressor use in septic shock. Intensive Care Med 34: 1646-1653, 2008.

3. Cornejo R, Downey P, Castro R, Romero C, Regueira T, Vega J, Castillo L, Andresen M, Dougnac A, Bugedo G and Hernandez G: High-volume hemofiltration as salvage therapy in severe hyperdynamic septic shock. Intensive Care Med 32: 713-722, 2006.

4. Cole L, Bellomo R, Journois D, Davenport P, Baldwin I and Tipping P: High-volume haemofiltration in human septic shock. Intensive Care Med 27: 978-986, 2001.

5. Oberholzer A, Oberholzer C and Moldawer LL: Sepsis syndromes: Understanding the role of innate and acquired immunity. Shock 16: 83-96, 2001.

6. Moss RB, Moll T, El-Kalay M, Kohne C, Soo HW, Encinas J and Carlo DJ: Th1/Th2 cells in inflammatory disease states: Therapeutic implications. Expert Opin Biol Ther 4: 1887-1896, 2004.

7. Abbas AK, Murphy KM and Sher A: Functional diversity of helper T lymphocytes. Nature 383: 787-793, 1996.

8. Harty JT, Tvinnereim AR and White DW: CD8+ T cell effector mechanisms in resistance to infection. Annu Rev Immunol 18: 275-308, 2000.

9. Walter U and Santamaria P: $\mathrm{CD}^{+} \mathrm{T}$ cells in autoimmunity. Curr Opin Immunol 17: 624-631, 2005.

10. Akira S, Uematsu S and Takeuchi O: Pathogen recognition and innate immunity. Cell 124: 783-801, 2006.

11. Holmes JH IV, Connolly NC, Paull DL, Hill ME, Guyton SW,Ziegler SF and Hall RA: Magnitude of the inflammatory response to cardiopulmonary bypass and its relation to adverse clinical outcomes. Infamm Res 51: 579-586, 2002.

12. Hotchkiss RS and Karl IE: The pathophysiology and treatment of sepsis. N Engl J Med 2003 348: 138-150, 2003.

13. Bone RC: Immunologic dissonance: a continuing evolution in our understanding of the systemic infammatory response syndrome (SIRS) and the multiple organ dysfunction syndrome (MODS). Ann Intern Med 125: 680-687, 1996.

14. .Levy MM, Fink MP, Marshall JC, Abraham E, Angus D, Cook D, Cohen J, Opal SM, Vincent JL and Ramsay G; SCCM/ ESICM/ACCP/ATS/SIS: 2001 SCCM/ESICM/ACCP/ATS/SIS International Sepsis Definitions Conference. Crit Care Med 31: 1250-1256, 2003.

15. Dellinger RP, Levy MM, Rhodes A, Annane D, Gerlach H, Opal SM, Sevransky JE, Sprung CL, Douglas IS, Jaeschke $\mathrm{R}$, et al; Surviving Sepsis Campaign Guidelines Committee including the Pediatric Subgroup: Surviving sepsis campaign: international guidelines for management of severe sepsis and septic shock: 2012. Crit Care Med 41: 580-637, 2013.

16. Martin GS, Mannino DM, Eaton S and Moss M: The epidemiology of sepsis in the United States from 1979 through 2000. N Engl J Med 348: 1546-1554, 2003.

17. Ronco C, Bellomo R, Homel P, Brendolan A, Dan M, Piccinni P and La Greca G: Effects of different doses in continuous venovenous haemofiltration on outcomes of acute renal failure: A prospective randomised trial. Lancet 356: 26-30, 2000.

18. Honore PM, Jamez J, Wauthier M, Lee PA, Dugernier T, Pirenne B, Hanique G and Matson JR: Prospective evaluation of short-term, high-volume isovolemic hemofiltration on the hemodynamic course and outcome in patients with intractable circulatory failure resulting from septic shock. Crit Care Med 28: 3581-3587, 2000.

19. Brendolan A, D'Intini V, Ricci Z, Bonello M, Ratanarat R, Salvatori G, Bordoni V, De Cal M, Andrikos E and Ronco C: Pulse high volume hemofiltration. Int J Artif Organs 27: 398-403, 2004.

20. Chu LP, Zhou JJ, Yu YF, Huang Y and Dong WX: Clinical effects of pulse high-volume hemofiltration on severe acute pancreatitis complicated with multiple organ dysfunction syndrome. Ther Apher Dial 17: 78-83, 2013

21. Peng Z, Pai P, Han-Min W, Jun Z, Hong-Bao L, Rong L and Chen $\mathrm{H}$ : Evaluation of the effects of pulse high-volume hemofiltration in patients with severe sepsis: A preliminary study. Int J Artif Organs 33: 505-511, 2010.

22. Ratanarat R, Brendolan A, Ricci Z, Salvatori G, Nalesso F, de Cal M, Cazzavillan S, Petras D, Bonello M, Bordoni V, Cruz D, Techawathanawanna N and Ronco C: Pulse high-volume hemofiltration in critically ill patients: A new approach for patients with septic shock. Semin Dial 19: 69-74, 2006.

23. Ratanarat R, Brendolan A, Piccinni P, Dan M, Salvatori G, Ricci Z and Ronco C: Pulse high-volume haemofiltration for treatment of severe sepsis: Effects on hemodynamics and survival. Crit Care 9: R294-R302, 2005. 
24. Hotchkiss RS, Osmon SB, Chang KC, Wagner TH, Coopersmith CM and Karl IE: Accelerated lymphocyte death in sepsis occurs by both the death receptor and mitochondrial pathways. J Immunol 174: 5110-5118, 2005

25. Chen X, Ye J and Ye J: Analysis of peripheral blood lymphocyte subsets and prognosis in patients with septic shock. Microbiol Immunol 55: 736-742, 2011.

26. Walley KR, Lukacs NW, Standiford TJ, Strieter RM and Kunkel SL: Balance of inflammatory cytokines related to severity and mortality of murine sepsis. Infect Immun 64: 4733-4738, 1996.

27. van der Poll T and Opal SM: Host-pathogen interactions in sepsis. Lancet Infect Dis 8: 32-43, 2008.

28. Calvano SE, Xiao W, Richards DR, Felciano RM, Baker HV, Cho RJ, Chen RO, Brownstein BH, Cobb JP, Tschoeke SK, MillerGraziano C, Moldawer LL, Mindrinos MN, Davis RW, Tompkins RG and Lowry SF: A network-based analysis of systemic inflammation in humans. Nature 437: 1032-1037, 2005

29. Yang RB, Mark MR, Gray A, Huang A, Xie MH, Zhang M, Goddard A, Wood WI, Gurney AL and Godowski PJ: Toll-like receptor-2 mediates lipopolysaccharide-induced cellular signalling. Nature 395: 284-288, 1998.
30. Zeytun A, van Velkinburgh JC, Pardington PE, Cary RR and Gupta G: Pathogen-specific innate immune response. Adv Exp Med Biol 598: 342-357, 2007.

31. Zhang FX, Kirschning CJ, Mancinelli R, Xu XP, Jin Y, Faure E, Mantovani A, Rothe M, Muzio M and Arditi M: Bacterial lipopolysaccharide activates nuclear factor-kappaB through interleukin-1 signaling mediators in cultured human dermal endothelial cells and mononuclear phagocytes. J Biol Chem 274: 7611-7614, 1999

32. Lorne E, Dupont H and Abraham E: Toll-like receptors 2 and 4: Initiators of non-septic inflammation in critical care medicine? Intensive Care Med 36: 1826-1835, 2010.

33. Kawai T and Akira S: The role of pattern-recognition receptors in innate immunity: Update on Toll-like receptors. Nat Immunol 11: 373-384, 2010.

34. Beutler B, Jiang Z, Georgel P, Crozat K, Croker B, Rutschmann S, Du X and Hoebe K: Genetic analysis of host resistance: Toll-like receptor signaling and immunity at large. Annu Rev Immunol 24: $353-389,2006$ 